\title{
CLINICAL SIGNIFICANCE OF THE CEREBRAL PERFORATING ARTERIES
}

\author{
Vaso Antunović ${ }^{1}$, Aleksandar Mirčić ${ }^{2}$, Slobodan Marinković ${ }^{3}$, \\ Luciano Brigante ${ }^{4}$, Miloš Mališ ${ }^{3}$, Biljana Georgievski ${ }^{5}$, Miljana Aksić ${ }^{3}$ \\ ${ }^{1}$ Clinical Center of Montenegro, University of Podgorica, Podgorica, Montenegro \\ ${ }^{2}$ Institute of Histology and Embryology, Faculty of Medicine, University of Belgrade, Serbia \\ ${ }^{3}$ Institute of Anatomy, Faculty of Medicine, University of Belgrade, Serbia \\ ${ }^{4}$ Department of Neurosurgery, University Hospital San Giovanni di Dio e Ruggi d'Aragona, Salerno, Italy \\ ${ }^{5}$ Department of Radiology, Sveti Sava Clinic, University of Belgrade, Serbia
}

Corresponding author: Slobodan Marinković, Institute of Anatomy, Faculty of Medicine, Belgrade, Serbia; e-mail: mocamarinkovic@med.bg.ac.rs

\begin{abstract}
There is scarce data in the contemporary literature regarding the correlation of the microanatomy of the perforating arteries, their atherosclerosis, and the ischemia in their territory. In order to examine, at least partially, those parameters, the perforating arteries of 12 brains were microdissected or their vascular casts were obtained. In addition, 30 specimens of the perforators were used for a histological and immunohistochemical study. Finally, radiological images of 14 patients with deep cerebral infarcts were examined following a selection among 62 subjects. It was found out that certain groups of the perforators ranged in number between 0 to 11 (1.1-8.4 on average). In addition to the origin from the parent vessels, some of the perforators also arose from the leptomeningeal branches. Occlusion of such a branch may result in both a superficial and a deep ischemic lesion. Besides, the common stems of certain perforators supplied both right and left portions of the corresponding brain regions. Occlusion of such a common trunk leads to bilateral infarction. The atherosclerosis of the perforating vessels, which was found in one third of the specimens, is the basis for the ischemic lesions development on their territory. Among the 62 patients with ischemic lesions, 14 had a deep cerebral infarcts, most often within the thalamus, as well as on the territory of the middle cerebral and the anterior choroidal artery perforators of the hemispheres. Our study showed that a strong correlation exists between certain microanatomical features, atherosclerosis, and region of supply of the perforating arteries, on the one hand, and location of the ischemic lesions on the other hand.
\end{abstract}

Keywords: perforating arteries, cerebral arteries, microanatomy, atherosclerosis, cerebral infarcts, radiology

\section{INTRODUCTION}

The largest cerebral arteries, that is, the vertebral artery (VA), basilar (BA), posterior cerebral (PCA), posterior communicating (PComA), internal carotid (ICA), anterior communicating (AComA), anterior cerebral (ACA) and middle cerebral artery (MCA), give rise to two main groups of branches, i.e. the superficial or leptomeningeal (pial), and the deep or perforating vessels (perforators) [1-4]. The former branches perfuse the peripheral parts of the cerebral and cerebellar hemispheres, portions of the diencephalon, and the superficial part of the brain stem [2-3].

On the other hand, the perforating vessels, which mostly arise from the initial segments of the large cerebral arteries, supply the central region of the cerebral hemisphere, the cerebellar 
roof nuclei, portions of the diencephalon, and the paramedian part of the brain stem [2, 5-11]. Occlusion of one or more of the perforating arteries causes a deep ischemic lesion, whilst a rupture of one of them results in intracerebral hemorrhage [12-16 ]. The cerebral atherosclerosis, which is the most frequent cause of the mentioned two types of strokes, was very rarely examined in the perforating arteries $[12,17]$. Similarly, there is insufficient data concerning the relationship of the supply region of the perforating vessels and the infarctions on their territory [18-21].

Accordingly, the aim of our study was, firstly, to examine the post mortem frequency of the atherosclerotic changes in a group of older individuals and, secondly, to correlate the characteristics of the perforating arteries in the anatomical specimens and the location of the central ischemic lesions diagnosed radiologically in a selected group of patients.

\section{MATERIAL AND METHODS}

The arteries of 10 brains, obtained during routine autopsies, were perfused with India ink and gelatine, and fixed in a 10\% formaldehyde solution for 3 weeks. None of the individuals had any neurological diseases. The arteries of the brains were then carefully dissected under the stereoscopic microscope using neurosurgical microinstruments. The dissection comprised not only the extracerebral, but also the intracerebral segments of the perforating vessels in order to determine their supply region as closely as possible. The additional 2 brains were injected with methylmethacrylate, and then immersed in 30\% potassium hydroxide for five days to obtain the arterial vascular casts. All of the procedures were approved by the authorities of the Institute of $\mathrm{Pa}$ thology, and by the Ethics Committee of the University Clinical Center.

From another group of 10 autopsic brains, whose large cerebral arteries macrosopically showed a high degree of atherosclerosis, 30 extracerebral segments of the BA, PCA, and MCA perforating branches were taken for microscopic examination. Each segment, following routine dehydration and clearing, was embedded in paraffin and sectioned serially in $5 \mu \mathrm{m}$-thick slices. Every tenth slice was stained with hematoxylin and eosin, whilst each eleventh and twelfth slice were used for immunohistochemical examination by applying the selected primary antisera according to the usual procedure [22]. All slices were treated for antigen retrieval prior to staining. The slices were stained for two antigens, i.e. alpha actin of the smooth muscle cells and collagen IV, respectivelly, by the streptavidin-biotin peroxidase complex method using as chromogens 3 -amino-9-ethylcarbazole. The sections were counterstained with Mayer's hematoxylin. The intensity of staining was evaluated semiquantitatively by two independent investigators. Finally, 14 arterial specimens of 10 additional brains, with an absence or a low degree of the visible atherosclerosis, were used as a control group.

As for the radiological material, a retrospective examination of the serial computerized tomographic (CT) scans (including two sets of the multislice CT scans), and magnetic resonance imaging (MRI) of 62 patients from the Radiological Department of the Sveti Sava Clinic was performed. The MRI examination was performed in both T1- and T-2 weighted sequences. The patients ( 39 males and 23 females) aged from 42 to 76 years (mean, 67.2). The examination was approved by the authorities of the Sveti Sava Clinic, and the Ethics Committee of the University Clinical Center. Fourteen patients from the mentioned group were selected based on the presence of deep ischemic cerebral lesions. The precise neuroradiological location of each lesion was determined. Unfortunately, angiography was not performed in any of the patients.

Finally, the statistical analysis comprised a range of certain parameters, as well as the counting of their mean values.

\section{RESULTS}

Three domains will be described in this section: the microanatomical features of the perforators, their atherosclerosis, and the location of deep ischemic lesions.

\section{Microanatomical characteristics}

The features of the perforating vessels in 12 brains were examined in an ascending order, i.e. from the vertebral artery inferiorly to the anterior cerebral artery superiorly.

The VA perforating branches, from 1 to 3 in number (mean, 3.2) (Table 1), were noticed in 
$62.5 \%$ of the cases. They arose directly from the right and/or left VA, but also from the roots of the anterior spinal artery and the latter artery itself. The origination from the adjacent posterior inferi-

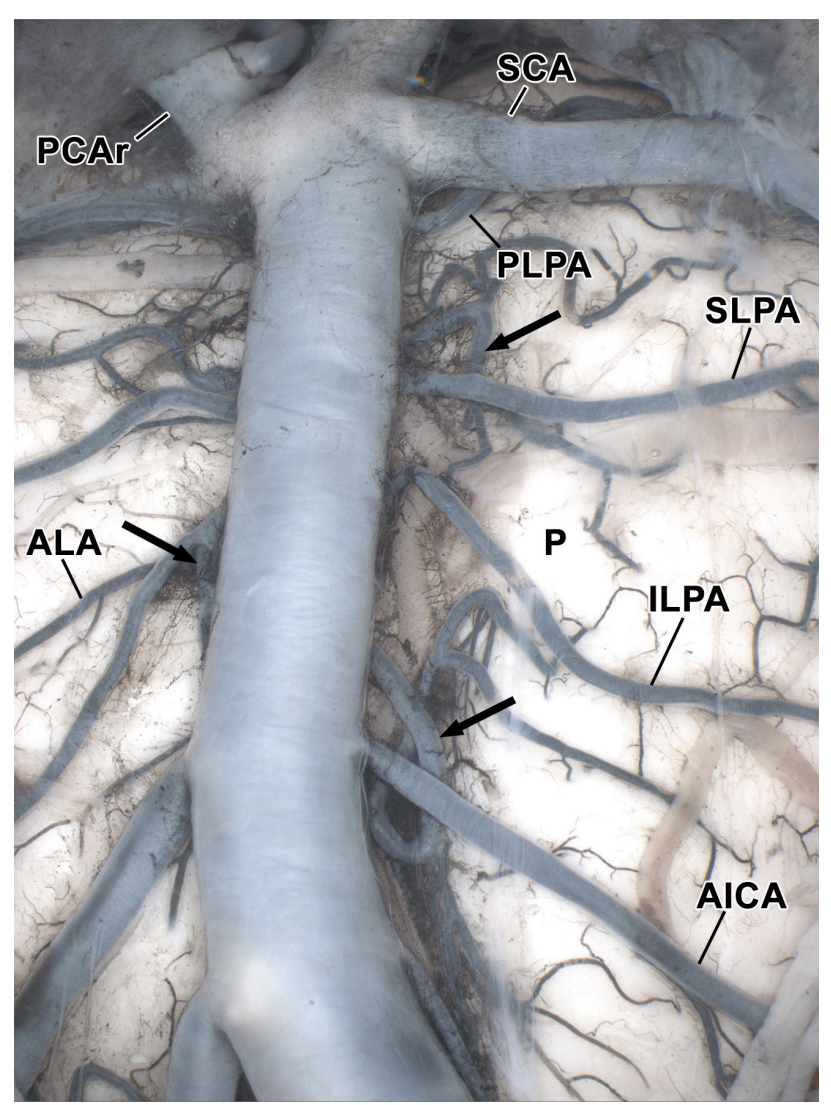

Figure 1.

or cerebellar artery was not found. The perforating vessels penetrated the foramen caecum and the anterior median sulcus of the medulla oblongata, and supplied its paramedian part all the way to the rhomboid fossa.

The BA perforators (Figure 1), which were constant vessels, ranged between 3 and 7 in number (Table 1). They always originated directly from the BA, but one or more of them also arose $(83.3 \%)$ in common with the short (anterolateral) pial vessels, or from the long pial arteries, such as the inferiolateral pontine, the superolateral pontine, or the posterolateral pontine branches, including the anterior inferior cerebellar and the superior cerebellar arteries (Figure 1). The caudal perforators entered the mentioned foramen caecum, the middle ones penetrated the edges of the pontine basilar sulcus, whilst the rostral vessels entered the most caudal part of the interpeduncular fossa. Nevertheless, the perforators supplied the paramedian region of the pons.
Table 1. Number of perforating arteries

\begin{tabular}{|c|c|c|}
\hline $\begin{array}{c}\text { No. of } \\
\text { specimens }\end{array}$ & $\begin{array}{c}\text { Parent } \\
\text { artery }\end{array}$ & $\begin{array}{c}\text { Number of perfora- } \\
\text { tors: range (mean) }\end{array}$ \\
\hline 24 & VA & $1-3(3.2)$ \\
\hline 12 & BA & $3-7(5.9)$ \\
\hline 24 & PCA (P1) & $1-6(3.1)$ \\
\hline 24 & PCA (P2) & $1-9(5.1)$ \\
\hline 24 & PComA & $1-2(1.1)$ \\
\hline 24 & ICA & $1-5(2.2)$ \\
\hline 24 & AChA & $3-6(4.1)$ \\
\hline 12 & AComA & $1-4(2.1)$ \\
\hline 24 & ACA & $1-4(2.9)$ \\
\hline 24 & MCA & $1-11(8.4)$ \\
\hline
\end{tabular}

There are two distinct groups of the perforating branches of the posterior cerebral artery, i.e. the thalamoperforating (TPA) and the thalamogeniculate arteries (TGA) (Figure 2).

The TPA perforators most often $(91.7 \%)$ originated from the initial (P1) segment of the right and the left PCA (Figure 2). In the remaining specimens $(8.3 \%)$, they arose only from the right or the left P1 segment, respectively, in which case a large common trunk of the perforators was noticed on the opposite side. In addition, one or more vessels originated from certain side branches, especially from the crural or peduncular vessels $(37.5 \%)$ of the PCA. The TPA may also arise by their own common trunks $(70.8 \%)$. One or more anastomoses involving the perforating vessels were observed in $62.5 \%$ of the cases.

Two sub-groups of the TPA perforators were distinguished, the mesencephalic and the diencephalic. The mesencephalic TPA entered the caudal part of the interpeduncular fossa or the medial part of the cerebral peduncle, and they perfused the paramedian and the central part of

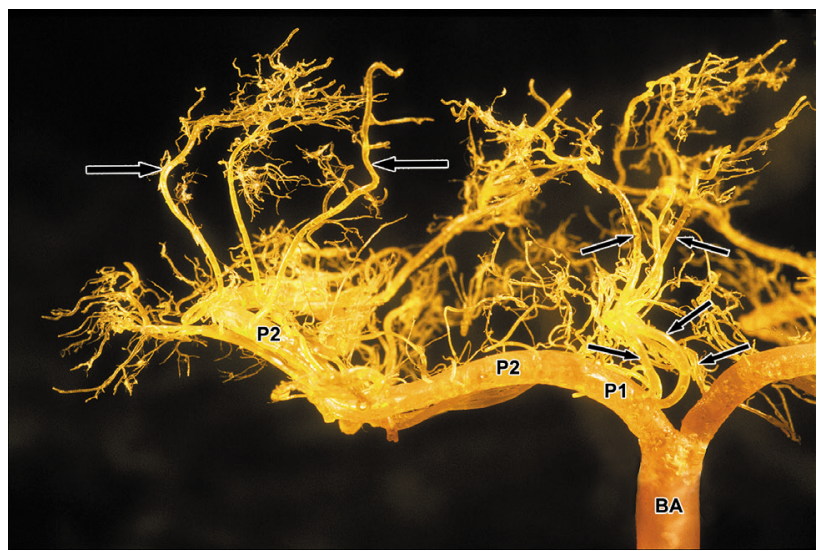

Figure 2. 
the midbrain. The diencephalic TPA penetrated the rostral part of the mentioned fossa, usually just behind the mammillary bodies. They supplied mainly the medial part of the thalamus (Figure 5).

The TGA perforators (Figure 2), which were from 1 to 9 in number (Table 1), arose from the distal part of the PCA, most often from its P2

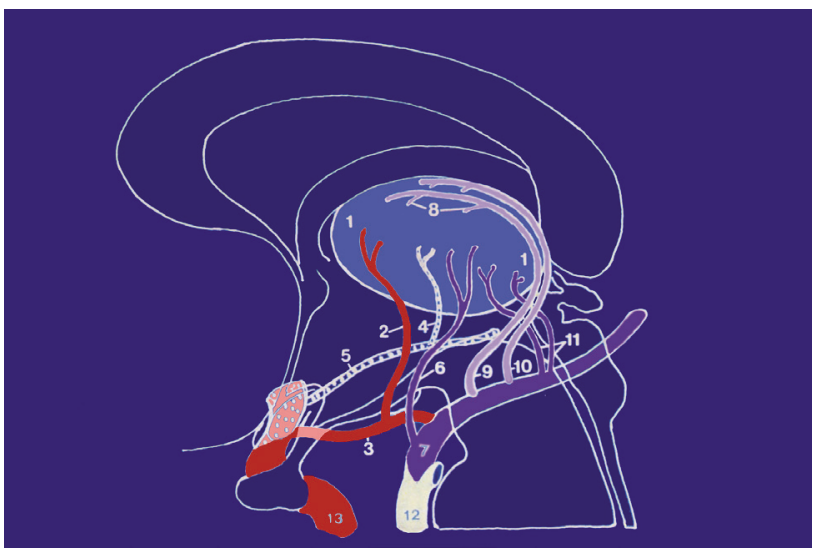

Figure 3.

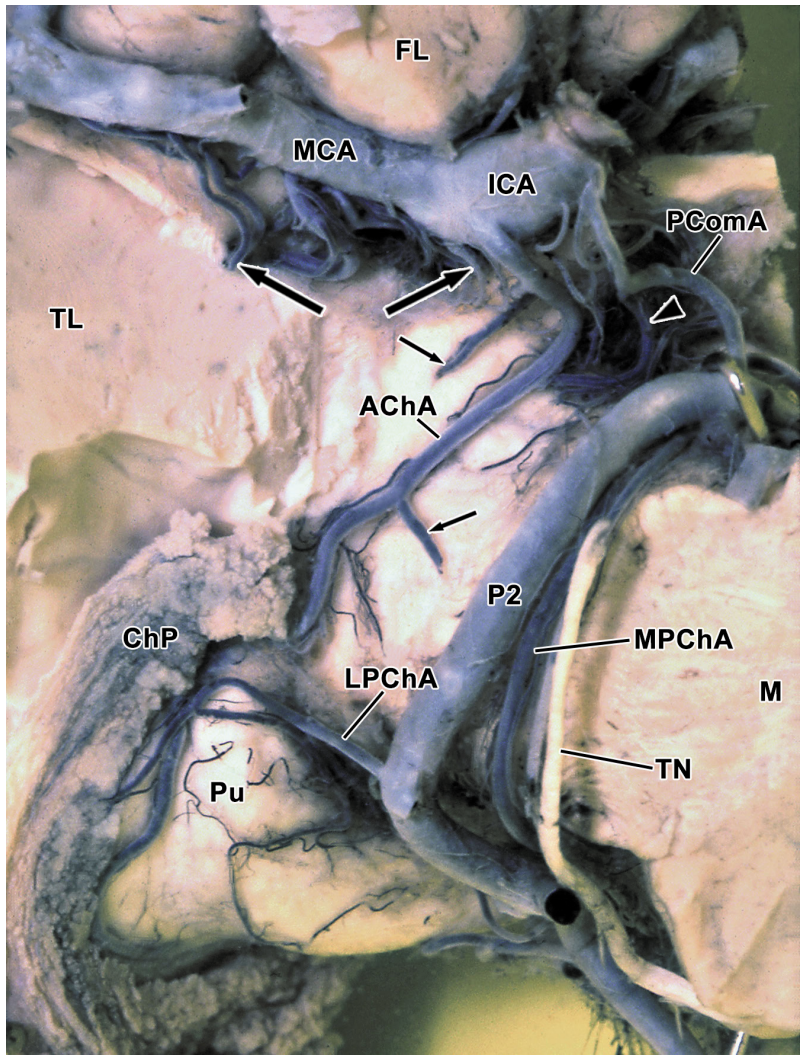

Figure 4.

segment, and rarely from the P3 segment. They infrequently $(12.4 \%)$ originated from the PCA branches, i.e. the temporal twigs, or the calcar- ine or the parieto-occipital arteries. The anastomoses involving the perforators were present in over a half of the specimens $(54.2 \%)$. The TGA most often penetrated the posterolateral part of the thalamus, including the pulvinar, which they supplied to a larger extent (Figure 3). They also perfused the medial geniculate body, parts of the subthalamus, and a portion of the posterior limb of the internal capsule. The remaining parts of the thalamus, except for the mediodorsal nucleus, were nourished by some other PCA branches, especially the medial and lateral posterior choroidal arteries, but they are not typical perforators (Figures 3 and 4).

The posterior communicating artery gave rise to one typical perforating branch, i.e. the premamillary artery (PMA) (Figure 4). This vessel had occasionally one or two anastomotic channels with the adjacent hypothalamic vessels. The PMA, after originating from the PComA, entered a triangular region surrounded by the cerebral peduncle, the mamillary body, and the optic tract. The PMA nourished the posterior part of the hypothalamus, the medial part of the subthalamus, and the anterior part of the thalamus (Figure 3).

The internal carotid artery, i.e. its supraclinoid (C4) segment, gave rise to 2.2 branches on average (Table 1). These perforators most often arose from the posterior ICA wall, closer or further to its bifurcation site. Besides, one of them was seen to arise from the origin site of the anterior choroidal artery in $8.3 \%$ of the specimens. The ICA perforators entered the rostral and medial part of the anterior perforated substance, just lateral to the optic chiasm. They most often supplied the genu of the internal capsule, and the adjacent part of the medial segment of the globus pallidus.

The AChA perforators (Figure 4) most frequently arose from the cisternal segment of the parent artery, i.e. in front of the choroid plexus, either directly or, less frequently $(29.2 \%)$, from the uncal or parahippocampal branches of the AChA. The perforators entered soon the most caudal part of the anterior perforated substance, usually along the optic tract, and rarely (4.2\%) through the tract itself. They were noticed to mainly supply parts of the medial and lateral segments of the globus pallidus, the retrolenticular portion and the ventral part of the posterior limb of the internal capsule, the most caudal part of the putamen, and the subthalamic nucleus. We were not sure whether they perfused the lateral part of the thalamus, close to the internal capsule. 
The AComA twigs, which were always present, may originate directly from the parent vessel, but also from the junction of the AComA and ACA, or from a pial branch, i.e. the subcallosal artery. These twigs usually supplied the lamina terminalis, the median part of the anterior commissure, the columns of the fornix, and the preoptic region of the hypothalamus.

The ACA always give rise to the typical perforating branches, which arose from its proximal (A1) segment near the carotid bifurcation, and the recurrent artery of Heubner, which originated close to the anterior communicating artery. Both types of the perforating vessels averaged 2.9 in number (Table 1). They penetrated the most rostral part of the anterior perforated substance. The vessels were noticed to nourish the anterior and inferior portion of the putamen and the head of the caudate nucleus, the lower part of the anterior limb of the internal capsule, and the rostral part of the basal forebrain.

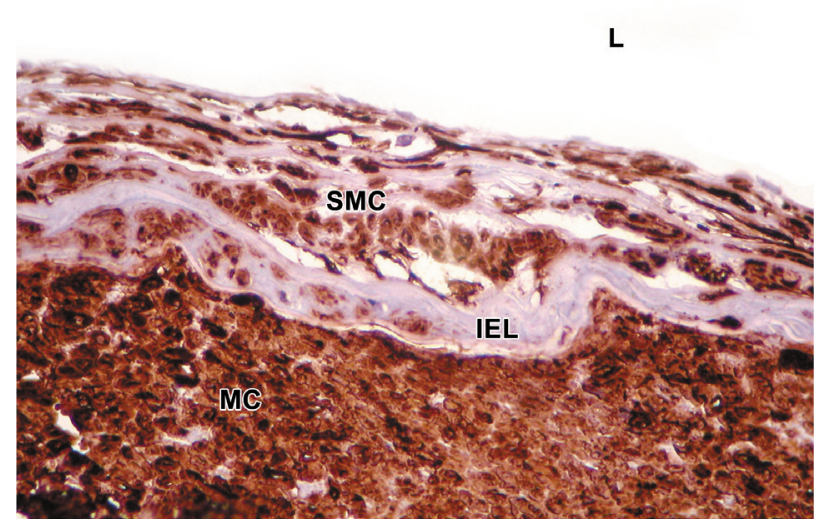

Figure 5.

The MCA gave rise to the largest number of the perforating arteries (Figure 4) (Table 1), which always arose directly from its proximal (M1) segment. However, one or more of these lenticulostriate vessels were found to originate from certain MCA pial branches, especially from the temporal twigs or the lateral orbitofrontal artery. The MCA perforators converged toward the carotid bifurcation and often entered both the medial and lateral part of the anterior perforating substance. They were noticed to perfuse most of the upper part of the internal capsule, and partially the lower portions of the anterior and posterior limbs, as well as the superolateral portion of the head of the caudate nucleus, part of the lateral segment of the globus pallidus, the largest portion of the putamen, small parts of the claustrum, and finally the innominate substance.

\section{Atherosclerosis}

Among the 10 patients with cerebral atheroslecoris, the corresponding changes were noticed in the perforating arteries wall in 3 cases, but not in the control group. In two of of the 3 specimens, the initial phases of atherosclerotic process were noticed, that is, an accumulation of certain cells within the subendothelial space, i.e. between the endothelial lining and the internal elastic lamina (Figure 5). The cellular elements mainly represented the smooth muscle cells, as confirmed by immunohistochemical staining for alpha actin of the smooth muscle cells (Figure 1). In the third patient, a typical atheroma was found in a perforating branch of the middle cerebral artery (Figure $6)$. The atheroma contained smooth muscle cells, fibroblasts, some detritus, and collagen IV. The internal elastic lamina was split sporadically.

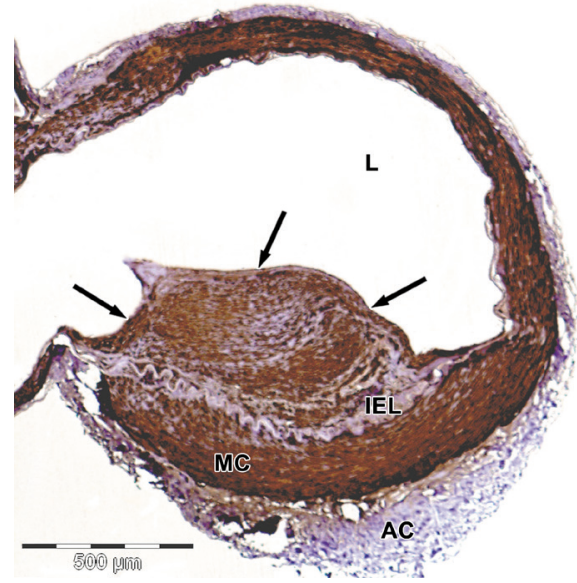

Figure 6.

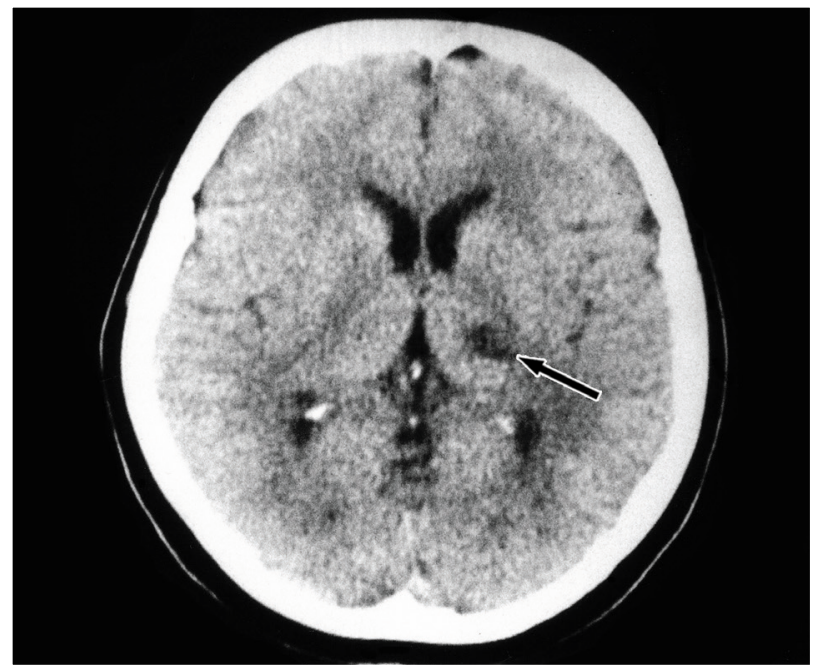

Figure 7. 


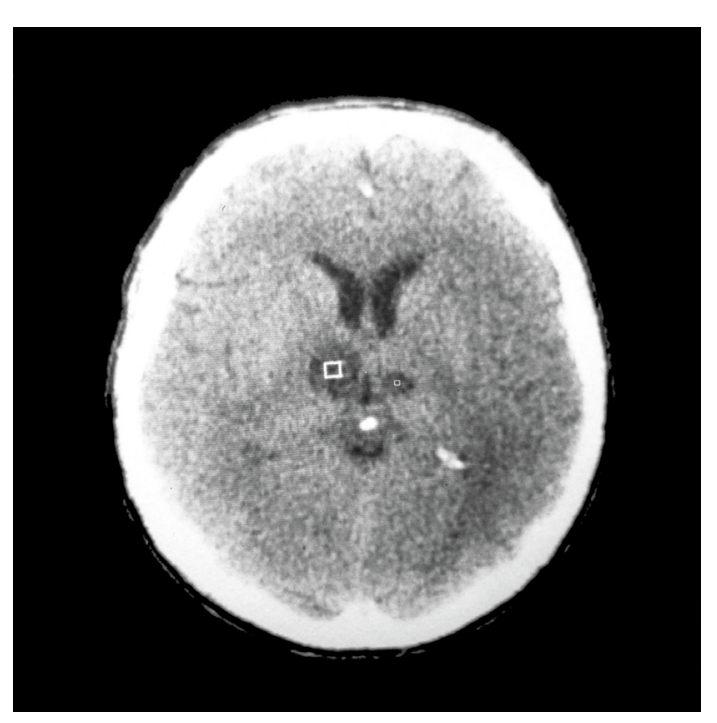

Figure 8.

Location of the ischemic lesions

Among the deep ischemic lesions in 14 patients, 1 was found in the pons, 1 in the midbrain, 4 in the thalamus, and the remaining 8 in the central hemispheric region.

Regarding the pontine and mesencephalic ischemic zones, they were noticed in their lateral part. One of the thalamic lesions was located in the lateral part of the thalamus (Figure 7), and the other two in the medial region. A double lesion was observed in one patient (Figure 8).

Among the 8 ischemic zones within the cerebral hemispheres, 1 was positioned in the extreme capsule. The next 2 smaller infarcts were noticed in the posterior area of the central hemispheric region. One of them occupied the caudal portion of the posterior limb of the internal capsule. The other one mainly affected the retrolenticular

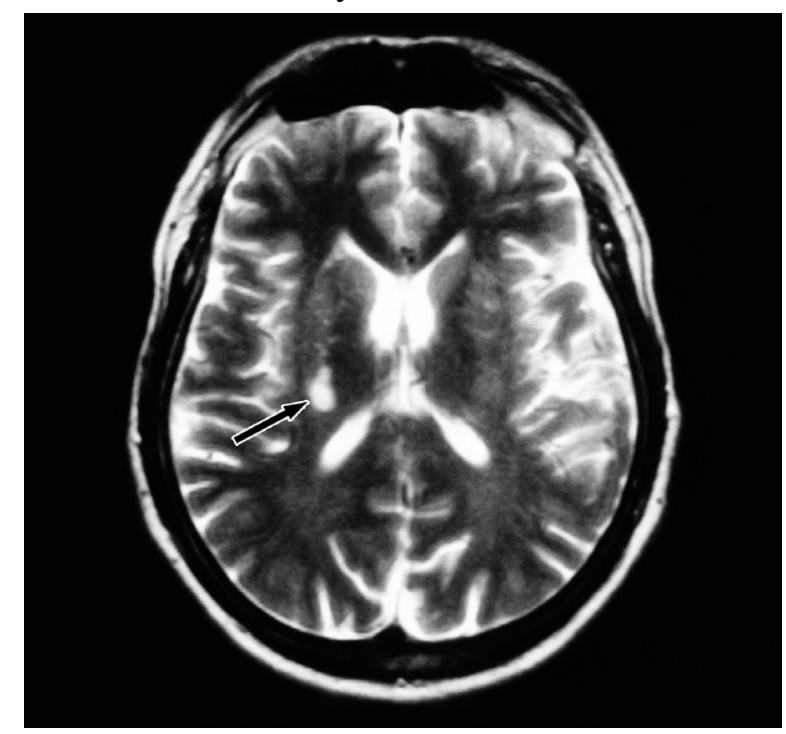

Figure 9. portion of the internal capsule and the adjacent most posterior part of the putamen (Figure 9). In the following patient, an ischemic zone was observed in the rostral part of the posterior limb of the internal capsule, and in the adjacent part of the globus pallidus and putamen (Figure 10). One patient presented a large capsulo-ganglionic

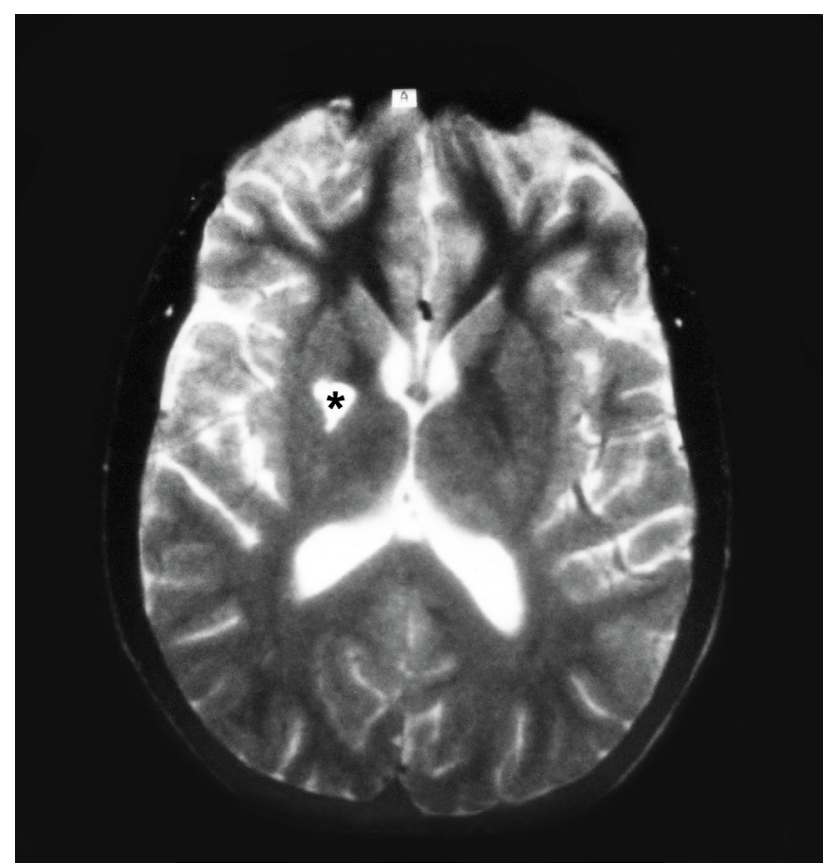

Figure 10.

infarct occupying most of the putamen, globus pallidus, and the adjacent portions of the internal capsule. In the next two patients, the ischemic zone was found in the upper part of the internal capsule, i.e. at the level of its genu and posterior limb. The last patient showed an ischemic lesion in the anterior limb of the capsule and the adjacent portion of the head of the caudate nucleus.

\section{DISCUSSION}

The results concerning the microanatomical features of the perforating arteries are similar to our previous findings [10, 23-31] and other authors' reports [2, 4-6, 16, 32-36]. Some of our present findings may have important clinical implications.

For instance, certain perforators were revealed to be absent on one side, either right or left. In these cases, a larger number of the perforators arose from the opposite parent artery. Consequently, one group of the perforators supplied both sides of the corre- 
sponding brain area. In addition, the "missing" perforators are partially supplemented by the branches of the neighboring ipsilateral arteries.

As already mentioned, several perforating vessels may originate from their own common stem. An occlusion of such a trunk will cause a much larger ischemic zone than an occlusion of a single perforator. Since some perforators occasionally arise from the side twigs, i.e. the leptomeningeal branches, of the parent artery, occlusion of a latter branch may lead to occurrence of both a superficial and a deep ischemic lesion. The association of those two types of infarcts was described by some other authors as well, although most often as a consequence of the global cerebral or systemic atherosclerosis [37].

Instead of intravascular occlusion, an external compression to the perforators may also compromise the blood flow in their lumina. This is especially true for the aneurysms located close to some perforators. Thus, by searching for the deep

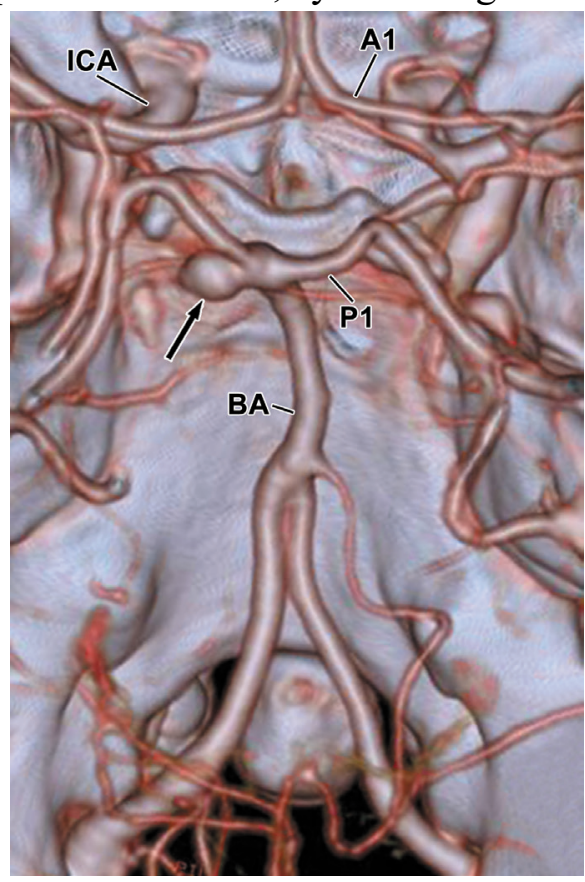

Figure 11.

infarcts, in a patient, we found a basilar artery aneurysm at the site of its bifurcation (Figure 11). Although the ischemic lesion was absent, during the operation, the neurosurgeons noticed that the aneurysm compressed, stretched and distorted some of the adjacent thalamoperforating arteries within the interpeduncular cistern, as was also reported by other authors in similar patients [38].

As mentioned in our study, the atherosclerosis of the perforating vessels was found in 3 of the 10 examined cases, and in one of them a large atheroma was present. The pathologic changes were noticed in patients with a visible atherosclerosis of the large arteries at the base of the brain, but in none within the control group. Similarly, some authors found a correlation between general atherosclerosis and the appearance of cerebral infarcts $[37,39]$. This may have three explanations. Firstly, atheromatous disease of the perforators themselves, which is accompanied by a narrowing of the vessels lumen. Secondly, occlusion of the orifice of a perforator by an atheroma of the parent vessels. Thirdly, thromboembolism of the perforators from a distant vessel, i.e. from the cervical segment of the carotid arteries [12].

As stated in our study and previous reports $[40,41]$, some perforating vessels were interconnected by anastomotic channels. However, the channels were observed only among the extracerebral segments of the perforators. This is why there is a minor significance of the anastomoses in the cases with perforator occlusion.

We stated in our previous studies that most of the perforators were less than $1 \mathrm{~mm}$ in diameter $[10,28]$. According to Fisher [17], the atherosclerotic process affects those perforators with 200 $\mu \mathrm{m}$ or more in diameter, which is the basis for a thromb formation and their occlusion. On the other hand, thinner perforators or their twigs are affected by small vessel diseases such as fibrinoid necrosis or lipohyalinosis $[12,14,17]$. There are two possible consequences of these processes, either an occlusion or a rupture of a perforating artery, respectively.

The ischemic lesions in the 14 selected patients showed various locations. One of them was present in the pons, and another one in the midbrain. However, since both of them were positioned in the lateral part of the brain stem, they were not caused by an occlusion of the perforating arteries $[2,8]$.

Thalamic infarctions were diagnosed in 4 patients. In one of them, the ischemic zone was present in the medial part of the left thalamus which is perfused by the thalamoperforating arteries. In another patient, bilateral lesions were found, predominantly in the medial part of the thalamus, i.e in the region supplied by the TPA as well (Figure 8 ). There are two explanations of the latter finding. Firstly, a multiple embolism from the vertebrobasilar system. Secondly, and most likely, occlusion of a large TPA common stem which nourished the medial region of both thalami. In the latter case, the larger lesion is located ipsilaterally, and the 
smaller one contralaterally. Finally, a lesion in the last patient was diagnosed in the posterolateral portion of the left thalamus (Figure 8), i.e. within the sensory thalamic nuclei which are on the territory of the thalamogeniculate perforators. Our findings are in agreement with the data of some anatomists and neurologists $[6,9,32]$.

Regarding the cerebral hemispheres, in one patient, a small infarct was located within the extreme capsule, i.e. between the claustrum and the insular cortex. However, this region is not supplied by typical MCA perforators [11].

One of the two following lesions occupied the caudal part of the posterior limb of the internal capsule, which is in the territory of the anterior choroidal artery $[5,7,9,19]$. Taking into account the fact that the pyramidal tract passes through the mentioned region of the internal capsule, as well as the thalamocortical bundle from the sensory thalamic nuclei, a hemiparesis and hemihypaesthesia could be expected $[19,42]$. In the next patient the infarct affected the most posterior part of the putamen and the retrolenticular portion of the internal capsule, which are also on the AChA territory (Figure 9). The latter patient had a partial damage of the geniculocalcarine tract in the retrolenticular portion of the internal capsule, so that he most likely presented quadrantanopia [42, 43].

In the next patient, an ischemic zone was positioned in the anterior limb of the internal capsule and the adjacent part of the head of the caudate nucleus. This is actually the territory of the perforating branches of the anterior cerebral artery $[5,11]$. Impairment of attention and memory, as well as confusion, anxiety and dysarthria could be expected in such subjects [43].

The following patient showed an ischemic lesion in the upper part of the internal capsule, close to the corona radiata. This part is supplied by the perforators of the middle cerebral artery [11]. One of the patients had a lower lesion (Figure 10), which occupied the rostral part of the posterior limb of the internal capsule, and the adjacent portion of the putamen and the lateral segment of the globus pallidus. It is mainly located in the MCA territory, but some contribution of the anterior choroidal arteriy cannot be excluded [11].

Finally, a large ischemic area was observed in the last patient, which occupied most of the putamen and globus pallidus, as well as the adjacent portions of the internal capsule. The ischemic zone also affected the surrounding region of the cerebral cortex and the subcortical white matter. It is obvious that this lesion is a result of thromboembolism, or a partial occlusion of the M1 segment of the middle cerebral artery $[5,9,11]$. In such patients, the morbidity and the mortality rate is higher than in those with an isolated ischemic lesion, either a deep or a superficial one [37].

Among the rostral group of the perforating arteries, we have not observed the ischemic lesions in the premamillary, internal carotid, and anterior communicating artery territory, meaning that they occur less frequently. As for the latter (AComA) territory, we described previously characteristic infarcts associated with the AComA aneurysms and accompanied by an amnesic syndrome [44].

The mentioned radiological images show two types of ischemic lesions, i.e. the lacunar infarcts and the larger ischemic zones. The former, which are up to $15 \mathrm{~mm}$ in diameter [12], are usually caused by occlusion of the small-sized perforating arteries, or of the primary or secondary side twigs of the larger perforators $[11,15,16$, 45]. Ischemic zones of larger size are produced by the occlusion of a larger perforating artery, a common stem of several perforators, or the initial segment of the parent cerebral artery [15]. A precise cause in these instances can be determined by performing magnetic resonance angiography, or diffusion-weighted MRI [15, 16. 46].

It should also be mentioned that some perforating arteries supply several structures. For instance, a perforator of the VA may nourish the hypoglossal nucleus, but also the pyramidal bundle and the medial lemniscus [2, 31]. Similarly, some BA perforators perfuse the abducens nucleus and the two mentioned bundles [2, 26]. A large mesencephalic vessel of the thalamoperforating branches of the PCA may supply the oculomotor nucleus and nerve, part of the red nucleus and the reticular formation, as well as the medial portion of the cerebral peduncle $[2,47,48]$.

A large diencephalic vessel among the thalamoperforating arteries may perfuse the medial part of the subthalamus, the posterior portion of the hypothalamus, the mediodorsal thalamic nucleus, parts of the adjacent nuclei, and even some areas of the midbrain $[6,32]$. Part of these diencephalic regions, but also the anterior thalamic nuclei, are supplied by the premamillary perforator of the PComA. A large ICA perforator nourishes the genu of the internal capsule, but also the medial segment of globus pallidus [7, 11]. A large perforating branch of the AChA may supply the subthalamic nucleus, the lateral geniculate body, 
a small part of the putamen, the posterior limb of the internal capsule $[33,49]$ and, according to some authors, the lateral part of the thalamus [6].

The AComA perforators nourish the lamina terminalis, the anterior commissure, the columns of the fornix, and the preoptic region of the hypothalamus $[36,44]$. A single perforator of the ACA may perfuse portions of the putamen, the lateral segment of the globus pallidus, and the head of the caudate nucleus, as well as part of the anterior limb of the internal capsule [5]. Finally, a single large lenticulostriate perforator of the MCA may supply the putamen, the internal capsule, the head of the caudate nucleus, the innominate substance, and part of the corona radiata $[5,11]$.

Due to the presented anatomical facts, dozens of the vascular syndromes were distinguished in patients with an occlusion of certain perforating arteries $[9,13,43,50]$.

\section{CONCLUSION}

The microanatomical features of the perforators have important pathological and neurological implications regarding the size, number, and location of the ischemic lesions. It was proved that the perforators can be directly affected by the atherosclerotic process. Knowledge of the perforator territory helps to determine which group of the perforators is involved in the ischemic lesions. Finally, precise neuroradiological location of the lesions can be useful in predicting the symptoms and signs which could appear in patients with such lesions.

\section{REFERENCES}

1. Stephens, R.B., \& Stilwell, D.L. Arteries and veins of the human brain. Charles C Thomas Publisher, Springfield, 1969, pp. 3-123.

2. Duvernoy, H.M. Human brainstem vessels. Springer, Berlin, Heidelberg, 1978, pp. 5-25.

3. Marinković, S., Gibo, H., Brigante, L., et al. Arteries of the brain and spinal cord. Anatomic features and clinical significance. De Angelis, Avellino, 1997, pp. 1-264.

4. Yasargil, M.G., Smith, R.D., Young, P.H., et al. Microneurosurgery. Microsurgical anatomy of the basal cisterns and vessels of the brain, diagnostic studies, general operative techniques and pathological considerations of the intracranial aneurysms. vol 1. Thieme, Stuttgart, 1984, pp. 54-164.

5. Rosner, S.S., Rhoton, A.L., Ono, M., et al. Microsurgical anatomy of the anterior perforating arteries. J Neurosurg 1984;61(3): 468-85.

6. Graff-Radford, N.R., Damasio, H., Yamada, T., et al. Nonhaemorrhagic thalamic infarction: Clinical, neuropsychological and electrophysiological findings in four anatomical groups defined by computerized tomography. Brain 1985;108(Pt 2): 485-516.

7. Ghika, J.A., Bogousslavsky, J., \& Regli, F. Deep perforators from the carotid system. Template of the vascular territories. Arch Neurol 1990;47(10): 1097-100.

8. Tatu, L., Moulin, T., Bogousslavsky, J., et al. Arterial territories of human brain: brainstem and cerebellum. Neurology 1996;47(5): 1125-35.

9. Tatu, L., Moulin, T., Bogousslavsky, J., et al. Arterial territories of human brain: cerebral hemisphere. Neurology 1998;50(6): 1699-708.

10. Djulejić, V., Marinković, S., Milić, V., et al. Common features of the cerebral perforating arteries and their clinical significance. Acta Neurochir (Wien) 2015;157(8): 1393-405.

11. Djulejić, V., Marinković, S., Georgievski, B., et al. Clinical significance of blood supply to the internal capsule and basal ganglia. J Clin Neurosci 2016;25: 19-26.

12. Fisher, M. Clinical atlas of cerebrovascular disorders. Wolfe, London, 1994, pp. 46-61.

13. Love, B.B., \& Biller, J. Neurovascular system. In: Goetz, C.G. Textbook of clinical neurology. 3rd ed. Saunders Elsevier, Philadelphia, 2007, pp. 405-34.

14. Rubin, E., \& Reisner, H.M. Essentials of Rubin's pathology. 5th ed. Lippincott Williams \& Wilkins. A Wolters Kluwer Business, Philadelphia, 2009, pp. 195-215.

15. Rabinstein, A.A., \& Resnick, S.J. Practical neuroimaging in stroke. A case-based approach. Saunders, Elsevier, Philadelphia, 2009, pp. 19-114.

16. Takahashi, S. Neurovascular imaging. MRI and microangiography. Springer, London, 2010, pp 53-130.

17. Fisher, C.M. Lacunar strokes and infarcts: a review. Neurology 1982;32(8): 871-6.

18. Hinshaw, D.B., Thompson, J.R., Hasso, A.N., et al. Infarctions of the brainstem and cerebellum: a correlation of computed tomography and angiography. Radiology 1980;137: 105-12.

19. Decroix, J.P., Graveleau, P., Masson, M., et al. Infarction in the territory of the anterior choroidal 
artery. A clinical and computerized tomographic study of 16 cases. Brain 1986;109: 1071-85.

20. Hupperts, R.M.M., Heuts-van Raak, E.P.M., \& Kessels, F. Infarcts in the anterior choroidal artery territory. Anatomical distribution, clinical syndromes, presumed pathogenesis and early outcome. Brain 1994;117: 825-34.

21. Marinković, S., Gibo, H., Milisavljević, M., et al. Anatomic and clinical correlations of the lenticulostriate arteries. Clin Anat 2001;14: 190-5.

22. Chan, K.-K., \& Lowe, J. Theory and practice of histological techniques. 5th Ed. Churchill Livingstone, London, 2002, pp. 271-320.

23. Marinković, S., Kovačević, M., \& Marinković, J. Perforating branches of the middle cerebral artery. Microsurgical anatomy of their extracerebral segments. J Neurosurg 1985;63(2): 266-71.

24. Marinković, S., Milisavljević, M., Kovačević, M. Interpeduncular perforating branches of the posterior cerebral artery. Microsurgical anatomy of their extracerebral and intracerebral segments. Surg Neurol 1986;26(4): 349-59.

25. Marinković, S., Milisavljević, M., \& Kovačević, M. Anatomical bases for surgical approach to the initial segment of the anterior cerebral artery: microanatomy of Heubner's artery and perforating branches of the anterior cerebral artery. Surg Radiol Anat 1986;8(1): 7-18.

26. Marinković, S., \& Gibo, H. The surgical anatomy of the perforating branches of the basilar artery. Neurosurgery 1993;33(1): 80-7.

27. Milisavljević, M., Marinković, S., Gibo, H., et al. The thalamogeniculate perforators of the posterior cerebral artery: the microsurgical anatomy. Neurosurgery 1991;28(4): 523-30.

28. Marinković, S., Gibo, H., \& Milisavljević, M. The surgical anatomy of the relationships between the perforating and the leptomeningeal arteries. Neurosurgery 1996;39(1): 72-83.

29. Marinković, S., Gibo, H., Brigante, L., et al. The surgical anatomy of the perforating branches of the anterior choroidal artery. Surg Neurol 1999;52(1): $30-6$.

30. Gibo, H., Marinković, S., \& Brigante, L. The microsurgical anatomy of the premamillary artery. J Clin Neurosci 2001;8(3): 256-60.

31. Marinković, S., Milisavljević, M., Gibo, H., et al. Microsurgical anatomy of the perforating branches of the vertebral artery. Surg Neurol 2004;61(2): 190-7.

32. Schlesinger, B. The upper brainstem in the human: its nuclear configuration and vascular supply. Springer-Verlag, Berlin, 1976. pp. 76-173.
33. Rhoton, A.L., Fujii, K., \& Fradd, B. Microsurgical anatomy of the anterior choroidal artery. Surg Neurol 1979;12(2): 171-87.

34. Gomes, F.B., Dujovny, M., Umansky, F., et al. Microsurgical anatomy of the recurrent artery of Heubner. J Neurosurg 1984;60(1): 130-39.

35. Vincentelli, F., Grisoli, F., Rabehanta, P., et al. Microsurgical anatomy of the cisternal course of the perforating branches of the posterior communicating artery. Neurosurgery 1990;26(5): 824-31.

36. Vincentelli, F., Lehman, G., Caruso, G., et al. Extracerebral course of the perforating branches of the anterior communicating artery: microsurgical anatomical study. Surg Neurol 1991;35(2): 98-104.

37. Lee, K., Kim, E.H., Song, D., et al. Lenticulostriate artery involvement is predictive of poor outcomes in superficial middle cerebral artery territory infarction. Yonsei Med J 2017;58(1): 123-30.

38. Yasargil, M.G., Smith, R.D., Young, P.H., et al. Microneurosurgery. Clinical considerations, surgery of the intracranial aneurysms and results. Vol 2. Thieme, Stuttgar1984b, pp. 3-264. Choi, H.Y., Yang, J.H., Cho, H.J., et al. Systemic atherosclerosis in patients with perforating artery territorial infarction. Eur J Neurol 2010;17(6): 788-93.

39. Marinković, S.V., Milisavljević, M.M., \& Kovacević, M.S. Anastomoses among the thalamoperforating branches of the posterior cerebral artery. Arch Neurol 1986;43(8): 811-4.

40. Marinković, S.V., Milisavljević, M.M., \& Marinković, Z.D. Microanatomy and possible clinical significance of anastomoses among hypothalamic arteries. Stroke 1989;20(10): 1341-52.

41. Carpenter, M.B. Core text of neuroanatomy. Williams and Wilkins, Baltimore, 1991, pp. 250-96.

42. Brazis, P.W., Masdeu, J.C., \& Biller, J. Localization in clinical neurology. Lippincott Williams \& Wilkins, Philadelphia, 2001, pp. 523-58.

43. Mugikura, S., Kikuchi, H., Fujii, T., et al. MR imaging of subcallosal artery infarct causing amnesia after surgery for anterior communicating artery aneurysm. Am J Neuroradiol 2014;35(12): 2293-301.

44. Boiten, J., \& Lodder, J. Lacunar infarcts. Pathogenesis and validity of the clinical syndromes. Stroke 1991;22(11): 1374-8.

45. Kang, C.K., Park, C.W., Han, J.Y., et al. Imaging and analysis of lenticulostriate arteries using 7.0-Tesla magnetic resonance angiography. Magn Reson Med 2009;61(1): 136-44.

46. Marinković, S., \& Gibo, H. The neurovascular relationships and the blood supply of the oculomotor 
nerve: the microsurgical anatomy of its cisternal segment. Surg Neurol 1994;42(6): 505-16.

47. Vitošević, Z., Marinković, S., Cetković M., et al. Intramesencephalic course of the oculomotor nerve fibers: microanatomy and possible clinical significance. Anat Sci Int 2013 Mar;88(2): 70-82.
48. Helgason, C., Caplan, L.R., Goodwin, J., et al. Anterior choroidal artery-territory infarction. Report of cases and review. Arch Neurol 1986;43(7): 681-6.

49. Alberstone, C.D., Benzel, E.C., Najm, I.M., et al. Anatomic basis of neurologic diagnosis. Thieme, New York, Stuttgart, 2009, pp. 514-41.

\title{
Резиме
}

\section{КЛИНИЧКОТО ЗНАЧЕЫЕ НА ПЕРФОРАНТНИТЕ АРТЕРИИ}

\section{Васо Антуновиќ ${ }^{1}$, Александар Мирчиќ ${ }^{2}$, Слободан Маринковиќ ${ }^{3}$, Луцијано Бриганте ${ }^{4}$, Милош Малиш ${ }^{3}$, Билјана Георгиевски ${ }^{5}$, Милјана Аксиќ ${ }^{3}$}

\author{
${ }^{1}$ Универзитетски клинички центар Црна Гора, Подгорица, Црна Гора \\ ${ }^{2}$ Институт за хистологија и ембриологија на Медицински фракултет, Белград, Србија \\ ${ }^{3}$ Анатомски институт Медицински факултет, Белград, Србија \\ ${ }^{4}$ Универзитетска неврохируршка клиника, Салерно, Италија \\ ${ }^{5}$ Радиолошко одделение, Универзитетска клиника „Свети Сава“, Белград, Србија
}

Во современата литература постојат скромни податоци за корелацијата на микроанатомските особини на перфорантните артерии, нивната атеросклероза и исхемијата во нивното подрачје. За да ги испитаме барем делумно овие параметри, направивме микродисекција на перфорантните артерии на 12 мозоци или беа добиени нивни васкуларни калапи. Покрај тоа, користевме 30 примероци на перфорантни садови за хистолошко и имунохистохемиско испитување. Најпосле, испитавме и радиолошки снимки на 14 пациенти со длабок церебрален инфаркт, кои беа избрани од вкупната бројка од 65 лица. Пронајдовме дека бројот на перфорантните крвни садови кај одредени групи варира меѓу 0 и 11 (во просек $1,1-8,4$ ). Освен одвојувањето од матичните садови, некои од перфорантните артерии потекнуваа и од лептоменингеалните гранки. Оклузија на една таква гранка може да предизвика и површинска и длабока лезија. Покрај тоа, заедничкото стебло на одредени перфорантни крвни садови ги снабдувало со крв и десностраните и левостраните делови на кореспондирачките подрачја на мозокот. Оклузија на такво заедничко стебло ќе предизвика билатерален инфаркт. Атеросклерозата на перфорантните садови, која ја пронајдовме во три наши примероци, е подлога за развој на исхемични лезии во нивното подрачје. Од испитаните пациенти со исхемични лезии, 14 имале длабоки церебрални инфаркти, најчесто во таламусот, како и во подрачјето на перфорантните садови на средната мозочна и на предната хороидна артерија на мозочните хемисфери. Нашата студија покажа дека постои голема корелација меѓу одредени микроанатомски особини и атеросклерозата и подрачјата што се снабдуваат со перфорантните артерии, од една страна, и локализацијата на исхемичните лезии, од друга.

Клучни зборови: перфорантни артерии, мозочни артерии, микроанатомија, атеросклероза, церебрални инфаркти, радиологија 